\title{
Feeding currents of particle-attached nanoflagellates - a novel mechanism for aggregation of submicron particles
}

\author{
Hideki Fukuda*, Isao Koike \\ Ocean Research Institute, University of Tokyo, 1-15-1, Minamidai, Nakano, Tokyo 164-8639, Japan
}

\begin{abstract}
In this study we present several lines of evidence suggesting a 'non-ingestive' mechanism by which nanoflagellates attached to sinking or suspended particles can enhance aggregation and enlargement of smaller particles in marine environments. Using epifluorescence microscopy, we observed the adhesion of model particles $(0.5 \mu \mathrm{m}$ fluorescent latex beads) in the feeding current from a particle-attached flagellate, Paraphysomonas imperforata, to the aggregate colonized by the flagellate. Particle counter measurements showed a significant increase in larger aggregates occurring only in the presence of living $P$. imperforata. The transfer rate of model particles to larger aggregates was determined by a flow cytometric technique and was observed to be higher in the presence of the attached flagellate than in free-living ones. In nutrient-enriched coastal seawaters, the transfer of model submicron particles to large particles (5 to $20 \mu \mathrm{m}$ ) was significantly reduced with the addition of eucaryotic and respiratory inhibitors (thiuram, $\mathrm{NaN}_{3}$ ). Ingestion of the latex beads by nanoflagellates did not explain the observed transfer rates of beads to larger particles. Collectively, the feeding current of attached flagellates, which has been ignored before as a mechanism for particle aggregation in marine environments, accelerates the attachment of submicron particles to larger particles. This process might be important in coastal productive waters, where both attached flagellates and submicron particles are abundant.
\end{abstract}

KEY WORDS: Heterotrophic nanoflagellates $\cdot$ Suspension feeding $\cdot$ Advective-diffusion $\cdot$ Colloidal coagulation $\cdot$ Sinking particles

Resale or republication not permitted without written consent of the publisher

\section{INTRODUCTION}

Submicron particles (SMP: a general term for diverse particles and aggregates of possibly different origins in the size range of 0.3 to $1 \mu m_{i}$ Koike et al. 1990, Buffle et al. 1998) represent a major component of marine particles (Yamasaki et al. 1998) and play an important role in oceanic biogeochemistry and food webs (Nagata \& Koike 1996, Nagata \& Kirchman 1997). Recent studies have suggested that aggregation of SMP and other particles is important in the formation of larger aggregates such as marine snow (Alldrege et al. 1993, Kepkay 1994, Buffle et al. 1998, Mari \& Burd 1998). The sinking of these aggregates is a major component of

*E-mail: hfukuda@ori.u-tokyo.ac.jp the downward transport of organic carbon and other elements in the oceans (Banse 1990, Lundsgaard \& Olesen 1997). Furthermore, aggregates are an important food resource for zooplankton (Dagg 1993). A better understanding of the factors that affect the coagulation rate of SMP is crucial for understanding material cycling in the ocean.

The initial step in the aggregation of SMP is the collision between SMP and other particles. In studying the dominant factors affecting the collision of particles, previous studies have focused mainly on physical processes such as Brownian transport, turbulent shear and differential sedimentation (Johnson \& Kepkay 1992, Jackson \& Burd 1998). These studies have generally neglected biotic factors, although some model studies have suggested that a biologically induced flow field, such as the protozoan feeding current, may signifi- 
cantly affect the rates at which SMP collide with other particles on the scale of low Reynolds numbers (Shimeta \& Jumars 1991, Shimeta 1993). This biological collision mechanism involving protozoan advective flow has been treated as a process similar to the differential sedimenting velocity of 2 particles (Johnson \& Kepkay 1992, Shimeta 1993).

Previous studies of Caron et al. (1982) and Silver et al. (1984) reported that in marine environments, large aggregates, such as settling particles, are densely colonized by protozoa. This could lead to the formation of a flow field caused by suspension-feeding protozoa attached to the aggregates around them. This biological flow can transport SMP and bacteria not only to the protozoan feeding apparatus but also to the aggregate's surface to which they are anchored. In contrast, the movement of free-swimming protozoa and bacteria has virtually no effect on the movement of the water around them. Studying the interactions between SMP, aggregates, and protozoa attached to the aggregates would provide a better understanding of the biotic regulation of SMP coagulation in the ocean.

The purpose of the present study was to test the effect of protozoans (heterotrophic nanoflagellates) attached to large particles on the advective transport of SMP to larger particles. We considered 5 to $20 \mu \mathrm{m}$ diameter particles as large particles because most freeliving nanoflagellates are excluded in this range, and these particles are abundant enough to analyze. Using a flow cytometer, we determined the rates at which a model SMP (polystyrene latex beads) adheres to large particles in both the presence and absence of attached flagellates (Paraphysomonas imperforata and natural flagellate assemblages). Our data demonstrate that the adhesion between SMP and large particles is substantially enhanced by the presence of attached flagellates and has important implications for modeling particle aggregation in oceanic systems.

\section{MATERIALS AND METHODS}

Organisms. A population of the heterotrophic nanoflagellate Paraphysomonas imperforata was isolated and maintained as described in Nagata \& Kirchman (1991). This species is a common member of protozoan communities associated with marine snow (Caron et al. 1982). The flagellates were cultured using the heatkilled marine bacterium Vibrio harveyi as prey. V. harveyi was cultured on LM broth $(\mathrm{NaCl}, 20 \mathrm{~g}$; Pepton, $10 \mathrm{~g}$; yeast extract, $5 \mathrm{~g}$; and Milli-Q water, $1 \mathrm{l}$ ) and harvested by centrifugation $(6000 \times g, 10 \mathrm{~min})$ during the early stationary phase. Harvested cells were washed with artificial seawater (ASW) (Nagata \& Kirchman $1991)$, and then killed by heat treatment $\left(60^{\circ} \mathrm{C}, 2 \mathrm{~h}\right.$;
Sherr et al. 1987). Heat-killed bacteria were washed twice by centrifugation $(6000 \times g, 10 \mathrm{~min})$, resuspended in ASW, and then filtered through $5 \mu \mathrm{m}$ poresize Nuclepore filters to remove large aggregates.

Microscopic observation. The behavior and feeding current of the flagellates attached to aggregates were observed under a differential-interference-contrast microscope equipped with an epifluorescence illumination apparatus (Axioplan, Zeiss). The flow pattern of their feeding current was examined by using hydrophilic fluorescent beads $(0.5 \mu \mathrm{m}$ diameter, polystyrene beads with carboxylate groups on their surface, Cat\# F-8813, Molecular Probes Inc.). The beads were added to the culture of flagellates at a final concentration of $10^{7}$ particles $\mathrm{ml}^{-1}$. Images were captured using a cooled CCD camera (C4880-7, Hamamatsu), recorded with a video recorder (NV-F400, Panasonic) and digitized to facilitate the trajectory analysis with the aid of video capture software (Photoshop, Adobe).

Changes in particle size distribution in flagellate culture. To examine the possible formation of large aggregates in the presence of flagellates, we determined the abundance and size distribution of particles in cultures of Paraphysomonas imperforata grown on heat-killed bacteria. Experiments were initiated by inoculating a preculture of flagellates to a suspension of heat-killed bacteria. The prey bacterial abundance varied from $6.3 \times 10^{6}$ to $1.0 \times 10^{8}$ cells ml ${ }^{-1}$ depending on the experiment. Samples were contained in 11 polycarbonate bottles and incubated at $20^{\circ} \mathrm{C}$ in the dark on a rolling wheel (rotation rate, 1 cycle $\mathrm{min}^{-1}$ ). Subsamples $(50 \mathrm{ml})$ were withdrawn during that period and fixed with buffered formalin (final conc. $2 \%$ ) for the determination of cell abundance and particle size distributions. A heat-killed control consisted of a suspension of heat-killed bacteria inoculated with a preculture of flagellates in the early stationary growth phase that had been inactivated by heat-treatment $\left(60^{\circ} \mathrm{C}, 2 \mathrm{~h}\right)$.

The cell abundance of bacteria and flagellates was determined by epifluorescence microscopy after DAPI staining (Porter \& Feig 1980). The coefficient of variation of this direct count was less than $15 \%$. Microscopic counts of the attached cells were multiplied by a factor of 2 to correct for flagellate cells on the opposite side of large particles. The abundance and size distribution of total particles were determined with a particle counter (Multisizer II, Coulter Electronic Ltd). A $15 \mu \mathrm{m}$ orifice was used for counting particles with an equivalent spherical diameter of 0.64 to $1.02 \mu \mathrm{m}$, whereas a $50 \mu \mathrm{m}$ orifice was used for 1.05 to $12.06 \mu \mathrm{m}$ particles.

Experimental transfer of fluorescent beads to large particles in flagellate culture. To examine the effect of attached flagellates on the aggregation of SMP, we determined the rates at which monodispersed, fluores- 
cent polystyrene beads (diameter, $0.5 \mu \mathrm{m}$, see above) were transferred to large ( 5 to $12 \mu \mathrm{m}$ ) particles in a culture of Paraphysomonas imperforata. In the culture, flagellates consisted of free-living and attached cells. Because we were interested in examining the role of attached and free-living flagellates separately, the flagellate culture was divided into 2 fractions. In the first case, an exponentially growing culture of flagellates grazing on heat-killed bacteria was placed in a $1 \mathrm{l}$ glass cylinder (diameter, $6.5 \mathrm{~cm}$; height, $30 \mathrm{~cm}$ ). The cylinder was left to stand for $1 \mathrm{~d}$ in the dark, and then the sedimented material was collected from the bottom ca $2 \mathrm{~cm}$ of the cylinder. This fraction (hereafter called the A-fraction) was enriched with large particles and attached flagellates. In the second case, a flagellate culture described above was gently filtered through a $3 \mu \mathrm{m}$ pore-size Nuclepore filter to remove large particles and attached flagellates. This filtrate (hereafter referred to as the F-fraction) contained mostly freeliving flagellates. Activity (ingestion rate of fluorescent beads) of free-living flagellates in the F-fraction was not changed by this filtration. Portions of A and F fractions were heat-inactivated $\left(60^{\circ} \mathrm{C}, 2 \mathrm{~h}\right)$ to serve as heatkilled controls, which were designated as 'heat-killed A-fraction' and 'heat-killed F-fraction', respectively. Three different mixtures of the flagellate cultures were prepared by mixing equal volumes of 2 different fractions: (1) 'A-fraction' + 'F-fraction', (2) 'F-fraction' + 'heat-killed A-fraction', and (3) 'heat-killed A-fraction' + 'heat-killed F-fraction'. Table 1 shows the abundance of flagellates in the 3 flagellate cultures after the mixing of 2 fractions at the start of the experiment. The difference of total surface area of large particles (5 to $20 \mu \mathrm{m}$ ) among the 3 cultures was within $20 \%$.

The experiment was initiated by adding fluorescent beads (see above, final conc. $4.1 \times 10^{6}$ particles $\mathrm{ml}^{-1}$ ) to the mixtures of flagellates. The cultures were incubated at $20^{\circ} \mathrm{C}$ in the dark. Subsamples were withdrawn over a period (for up to $3 \mathrm{~h}$ ) and fixed with buffered formalin (final conc. $2 \% \mathrm{v} / \mathrm{v}$ ) or ice-cold glutaraldehyde (Sieracki et al. 1987). Formalin-fixed samples were used for counting bacteria, flagellates and fluorescent beads. Fluorescent beads were counted by using a flow cytometer (BRYTE HS, BioRad) with excitation/emission wavelengths (nm) of 470 to $490 / 515$ to 565 . Fluorescence was triggered by a forward angle light (FAL) scatter signal of large particles $(5$ to $20 \mu \mathrm{m}$ ) to estimate the number of fluorescent particles associated with large particles. For this estimation, it was assumed that the fluorescence intensity associated with a given particle relates linearly to the number of fluorescent beads transferred to it. The quenching of fluorescence from the opposite side of the large particle may occur, which would cause an underestimation of the number of transferred beads. FAL was calibrated with standard beads (Coulter Electronic Ltd). Ice-cold glutaraldehyde-fixed samples were used for counting fluorescent beads in food vacuoles to estimate ingestion rate of beads by flagellates (Sherr et al. 1987).

Transfer of fluorescent beads to large particles in coastal seawater. We conducted an experiment to examine if adhesion of fluorescent beads to large (5 to $20 \mu \mathrm{m})$ particles is stimulated by protozoan assemblages in coastal seawater. The water sample was collected from a pier at Aburatsubo Bay $\left(35.9^{\circ} \mathrm{N}\right.$, $139.38^{\circ} \mathrm{E}$ ) on February 11, March 12 and April 5, 1999. The sample water collected on February 11 was filtered through a $68 \mu \mathrm{m}$ mesh to remove zooplankton, contained in a 201 polycarbonate bottle, enriched with nutrients $\left(\mathrm{NO}_{3}{ }^{-}, 10 \mu \mathrm{M}, \mathrm{PO}_{4}{ }^{3-}, 2 \mu \mathrm{M}\right)$ and then incubated at $20^{\circ} \mathrm{C}$ under a $12: 12 \mathrm{~h}$ light:dark photoperiod. On March 12 and April 5, 11 of filtered seawater (68 $\mu \mathrm{m}$ mesh) was inoculated into $20 \mathrm{l}$ of GF/F filtered sample water, and the incubation was conducted under the same conditions as described above after further enrichment of nutrients $\left(\mathrm{NO}_{3}{ }^{-}, 20 \mu \mathrm{M}, \mathrm{PO}_{4}{ }^{3-}\right.$, $4 \mu \mathrm{M})$. Subsamples were taken to determine the rates of the adhesion between fluorescent beads and large particles and the rates at which attached protozoa and ciliates ingest fluorescent beads. Chlorophyll a concentration (fluorometry; Suzuki \& Ishimaru 1990), the abundance of bacteria, flagellates and ciliates (epifluorescence microscopy; Porter \& Feig 1983, Sherr \& Sherr 1983), and the abundance and size distributions of particles (Coulter particle counting) were also deter-

Table 1. Summary of living or heat-killed (HK) flagellate abundance in 3 Paraphysomonas imperforata cultures of the bead transfer experiment

\begin{tabular}{|lccccc|}
\hline Cultures & Mixed fractions & & \multicolumn{2}{c|}{ Flagellate abundance $\left(10^{3}\right.$ cells ml $\left.{ }^{-1}\right)$} \\
& & Attached & Non-attached & HK \\
attached & HKon-attached \\
& & & 3.3 & - & - \\
(1) Attached flagellate culture & 'A-fraction' + 'F-fraction' & 31 & 3.3 & 6 \\
(2) Free-living control & 'HK A-fraction' + 'F-fraction' & - & 35 & 3.3 \\
(3) Heat-killed control & 'HK A-fraction' + 'HK F-fraction' & - & - & 41 \\
\hline
\end{tabular}



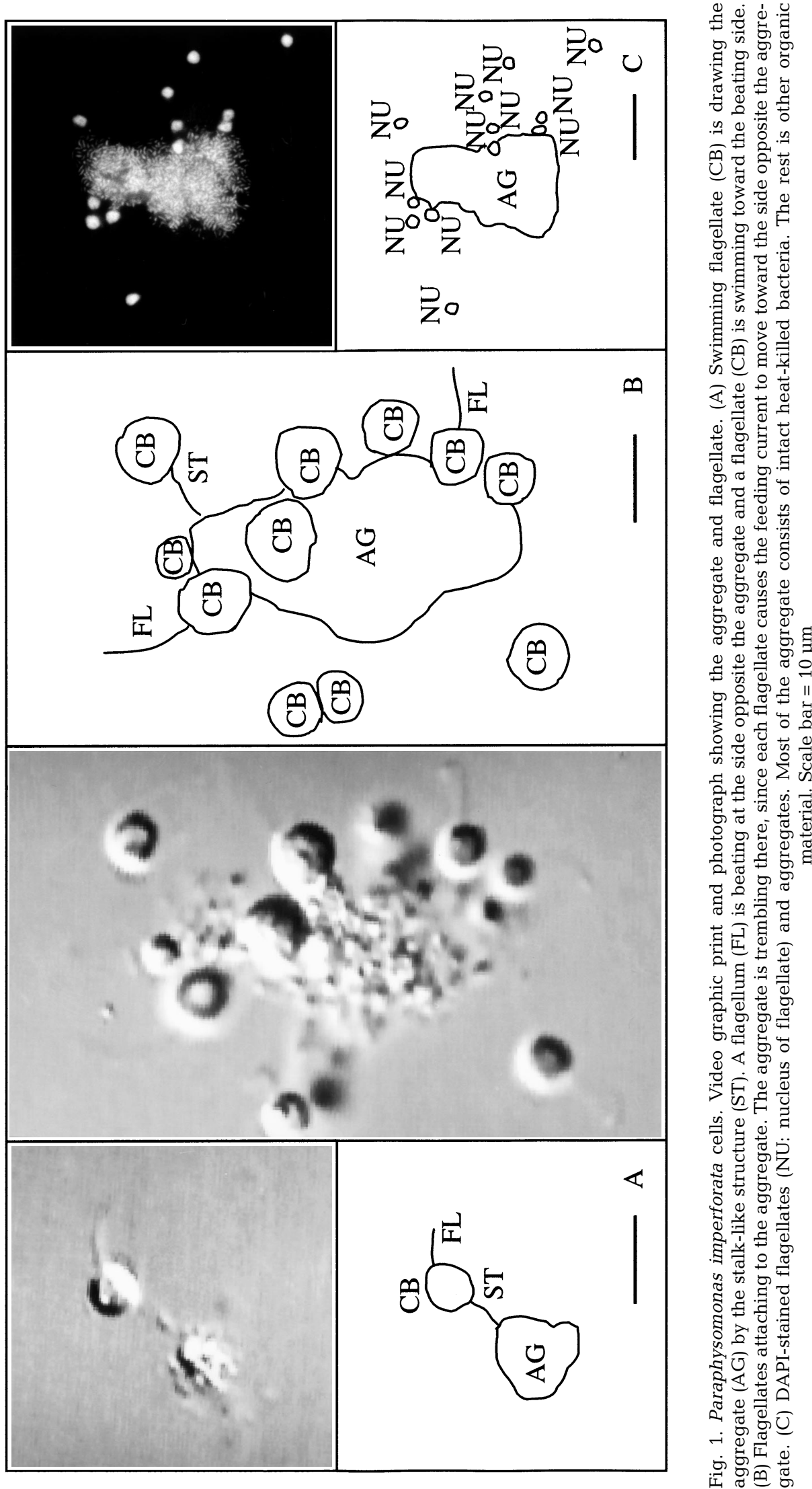
mined. During the counting of attached flagellates we could not discriminate between suspension feeders and those grazing on adhered bacteria and materials on the aggregate. Consequently the data include both types. The density of attached flagellates was calculated from the total abundance of attached flagellates and the particle number determined by the particle counter.

For the determination of transfer rates, a subsample in a $250 \mathrm{ml}$ polycarbonate bottle was used. Two controls were also prepared: one with eucaryotic inhibitor, thiuram (final conc. $20 \mu \mathrm{M}$; Taylor \& Pace 1987), and the other with an inhibitor of the respiratory chain (sodium azide; final conc. $0.02 \%$, w/v). One sample and 2 controls were amended with fluorescent beads (final conc. $1.5 \times 10^{6}$ particles $\mathrm{ml}^{-1}$ ) and incubated for up to $24 \mathrm{~h}$ at $20^{\circ} \mathrm{C}$ in the dark. The abundance of beads associated with large (5 to $20 \mu \mathrm{m}$ ) particles was monitored every $6 \mathrm{~h}$ using a flow cytometer. For determination of ingestion rates, the subsample contained in the $250 \mathrm{ml}$ bottle was amended with fluorescent beads (final conc. $1.5 \times 10^{6}$ particles $\mathrm{ml}^{-1}$ ) and incubated for $15 \mathrm{~min}$ at $20^{\circ} \mathrm{C}$ in the dark. After incubation, the sample was fixed with ice-cold glutaraldehyde, and the number of beads in food vacuoles was counted to estimate ingestion rates of flagellates and ciliates (Sherr et al. 1987). Organisms were stained by FITC and DAPI (Sherr \& Sherr 1983) to discriminate between beads adhering to the cell surface and those ingested.

\section{RESULTS}

\section{Microscopic observations}

In the cultures, Paraphysomonas imperforata were either free-living or attached. Attached forms mostly resided on organic aggregates (size 1 to $50 \mu \mathrm{m}$ ) that apparently consisted of heat-killed bacteria and other organic materials (Fig. 1A,B,C). The number of attached flagellates per aggregate varied in the range of 1 to 20 cells. A flagellate cell body was anchored to the aggregate by a stalk. The average length of the stalk was $2.6 \pm 1.6 \mu \mathrm{m}(\mathrm{n}=20)$, corresponding to $0.70( \pm 0.41)$ $\times$ cell diameter. The attached flagellates extended their flagella in the direction opposite that of the attachment site. The beating of the flagella created a feeding current moving toward the flagellate, attracting prey cells and other particles in the vicinity. When a particle hit the flagellum, the ingestion reaction was triggered. This event was characterized by a short interruption of beating, which was often associated with the bending of the flagellum toward the flagellate cell body. The successful capture of particles was followed by phagocytotic engulfment of prey particles.
It is notable, however, that most of the particles transported by the feeding current passed near the cell without being captured by flagellates (Fig. 2A,B) and occasionally adhered to aggregates (Fig. 2C,D). These observations suggest that the feeding current could affect coagulation of small particles.

\section{Changes in particle size distribution in flagellate culture}

The abundance of both free-living and attached flagellates increased with a decrease in the abundance of heat-killed bacteria in non-treatment culture (Table 2). During the growth of flagellates, size distribution of particles determined by a particle counter changed drastically. At the beginning of the experiment, size distribution skewed towards the smallest size, reflecting the size distribution of heat-killed bacteria. A distinctive peak appeared at 4.06, 2.62 and $2.36 \mu \mathrm{m}$ after the incubation for 29,43 and $64.5 \mathrm{~h}$, respectively. This corresponded to the diameter of free-living flagellates at each sampling time as determined from microscopic observations. Notably, quantities of large particles (5 to

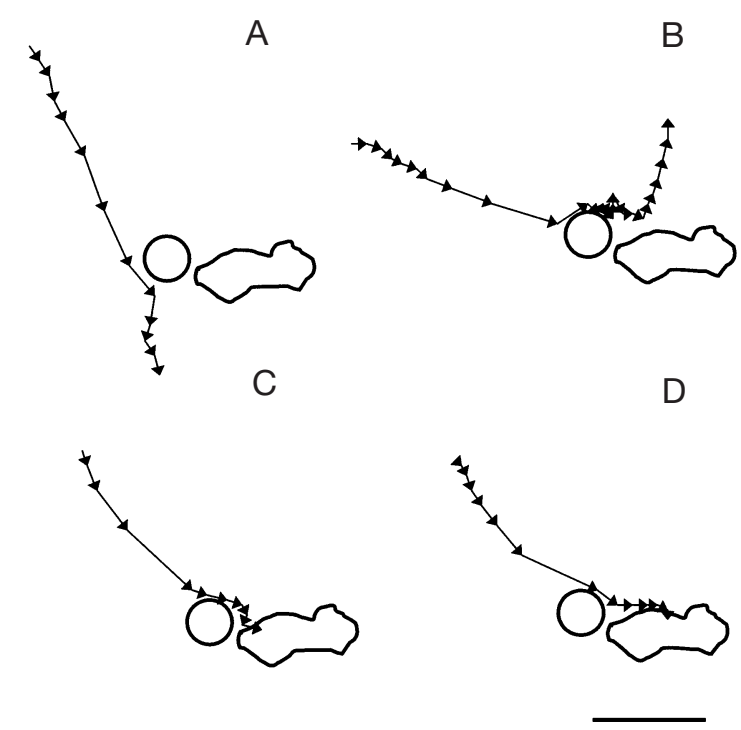

Fig. 2. Observed trajectories of the fluorescent latex beads attracted by the feeding current of attached flagellates. (A) Most of the attracted beads passed near the attached flagellate without any contact with the flagellates or the aggregate. (B) In some cases, beads collided with the cell surface of the flagellates and stayed in the field around the cell surface. Two occasions on which the beads collided with the aggregate behind the attached flagellate were observed: (C) the bead velocity decreased after entering into the space behind the flagellate; and (D) the bead contacted with the aggregates without entering into the space between the flagellates and the aggregate. Arrowheads indicate the movement of the bead within $0.2 \mathrm{~s}$. Scale bar $=10 \mu \mathrm{m}$ 
Table 2. Change in total volume of cells and particles in the culture of Paraphysomonas imperforata $\left(10^{5} \mu \mathrm{m}^{3} \mathrm{ml}^{-1}\right)$. Error bar indicates $\pm 1 \mathrm{SD}(\mathrm{n}=5)$. ${ }^{*}$ Difference not statistically significant $(\mathrm{p}>0.05)$

\begin{tabular}{|c|c|c|c|c|c|c|c|}
\hline Time (h) & $\begin{array}{l}\text { Heat-killed } \\
\text { free bacteria }\end{array}$ & $\begin{array}{l}\text { Free-living } \\
\text { flagellates }\end{array}$ & $\begin{array}{l}\text { Attached } \\
\text { flagellates } \\
\text { (Va) }\end{array}$ & $\begin{array}{c}<5 \mu \mathrm{m}^{\mathrm{a}} \\
\text { particles } \\
(\mathrm{Vs})\end{array}$ & $\begin{array}{l}>5 \mu \mathrm{m} \\
\text { particles } \\
\text { (Vl) }\end{array}$ & $\begin{array}{l}\text { Aggregates } \\
\text { (Vl-Va) }\end{array}$ & $\frac{\text { Increase in aggregates }(\Delta \mathrm{Vl}-\mathrm{Va})^{\mathrm{b}}}{\text { Decrease in }<5 \mu \mathrm{m}(\Delta \mathrm{Vs})}$ \\
\hline \multicolumn{8}{|c|}{ Non-treatment } \\
\hline 0 & $58 \pm 2.3$ & 0.21 & $<0.03$ & $110 \pm 5.6$ & $5.5 \pm 1.0$ & 5.5 & - \\
\hline 29 & $44 \pm 0.9$ & 2.0 & 0.21 & $100 \pm 2.6$ & $19 \pm 2.9$ & 19 & $130(\%)$ \\
\hline 43 & $1.8 \pm 0.1$ & 17 & 1.3 & $41 \pm 2.8$ & $26 \pm 0.8$ & 25 & $28(\%)$ \\
\hline 64.5 & $2.7 \pm 0.2$ & 18 & 0.92 & $26 \pm 1.3$ & $11 \pm 1.1$ & 10 & $5.5(\%)$ \\
\hline \multicolumn{8}{|c|}{ Heat-treatment } \\
\hline 0 & $50 \pm 2.5$ & - & - & $120 \pm 7.0$ & $5.5 \pm 1.2$ & 5.5 & - \\
\hline 29 & $47 \pm 2.8$ & - & - & $120 \pm 6.3$ & $6.0 \pm 0.9$ & 6 & $\mathrm{NS}^{*}$ \\
\hline 43 & $47 \pm 1.4$ & - & - & $110 \pm 3.2$ & $5.5 \pm 1.0$ & 5.5 & $\mathrm{NS}^{*}$ \\
\hline 64.5 & $61 \pm 4.2$ & - & - & $130 \pm 6.3$ & $4.3 \pm 0.9$ & 4.3 & $\mathrm{NS}^{*}$ \\
\hline
\end{tabular}

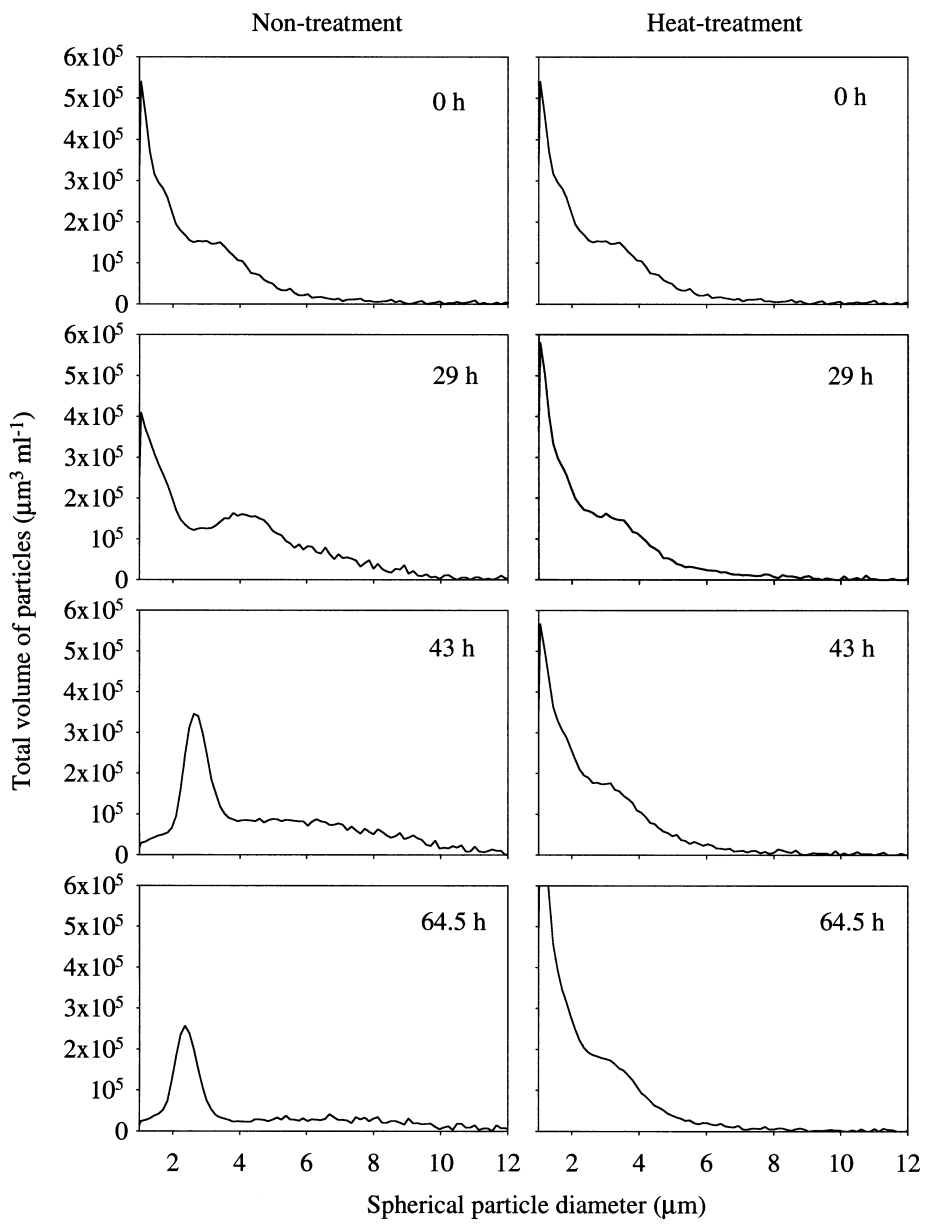

Fig. 3. Change of particle size distribution during the culture of Paraphysomonas imperforata. The culture inoculated growing flagellates (non-treatment) or heat-killed flagellates (heat-treatment) at the beginning of the experiment
$12 \mu \mathrm{m}$ ) appeared after $29 \mathrm{~h}$ of incubation (Fig. 3, Table 2). These large particles did not show any distinctive peaks. In the heat-killed control, on the other hand, the abundance of large particles and the pattern of particle size distribution changed little during the whole incubation period (Fig. 3, Table 2).

Table 2 summarizes the changes in the total volume of living and non-living particles during the incubation. Significant amounts of large particles ( 5 to $12 \mu \mathrm{m}_{i} \mathrm{Vl}$ ) were produced along with the decrease in small particles ( 1 to $5 \mu \mathrm{m}$; Vs), i.e. the increase in the total volume of 5 to $12 \mu \mathrm{m}$ particles accounted for $35 \%$ of the decrease in 1 to $5 \mu \mathrm{m}$ particles after $43 \mathrm{~h}$ of incubation (Table 2). The total volume of 5 to $12 \mu \mathrm{m}$ particles decreased by $42 \%$ between 46 and $64 \mathrm{~h}$. At $64 \mathrm{~h}$, we observed many large flocs (approximate size, >1 mm), although these particles were not determined by particle counting. There was no significant increase in the total volume of 5 to $12 \mu \mathrm{m}$ particles in the heat-killed control.

One component of the 5 to $12 \mu \mathrm{m}$ particles was flagellate cells attached to aggregates. However, the volume of flagellate cells (Va), estimated by microscopic measurements taken from the experiments with a variable number of prey cells (range 0.63 to $10 \times 10^{7}$ cells $\mathrm{ml}^{-1}$ ), accounted for only a small fraction $(<20 \%)$ of the total volume of 5 to $12 \mu \mathrm{m}$ particles (Fig. 4A). It appears that the increase in total volume of 5 to $12 \mu \mathrm{m}$ particles during the incubation for up to $46 \mathrm{~h}$ was primarily due to the increase of aggregates (Vl - Va) consisting of bacteria and other organic detritus. 

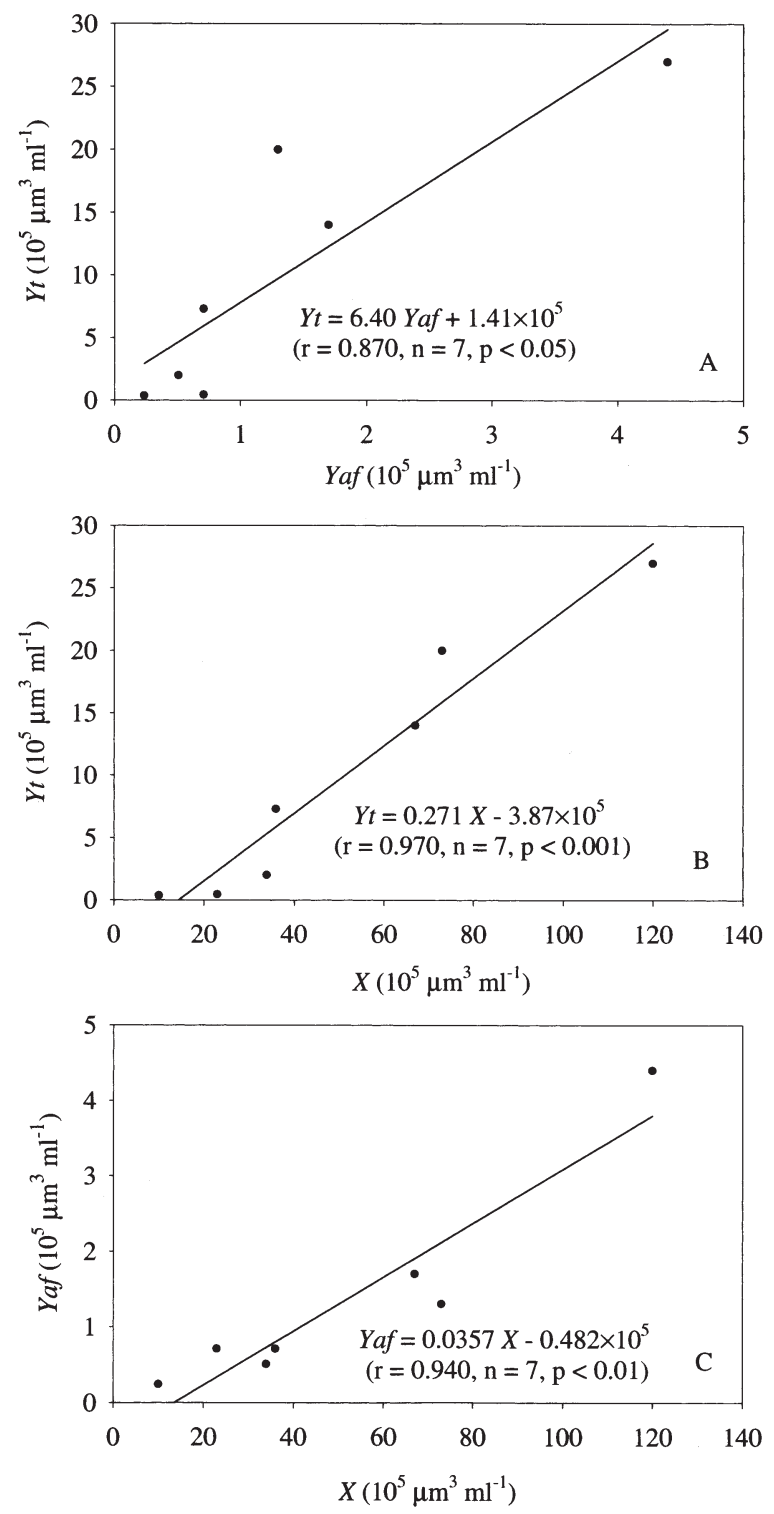

Fig. 4. Comparison of various particle volumes in the Paraphysomonas imperforata culture: (A) between increase in attached flagellate fraction (Yaf: see text) and increase in 5 to $12 \mu \mathrm{m}$ total particle fraction produced $(Y t)$, (B) between decrease in 1 to $5 \mu \mathrm{m}$ total particle fraction $(X)$ and $Y t$, and (C) between $X$ and Yaf

The total volume of 5 to $12 \mu \mathrm{m}$ particles produced (Yt) was related to the total volume of 1 to $5 \mu \mathrm{m}$ particles removed $(X)\left(Y t=0.271 X-3.87 \times 10^{5}[\mathrm{r}=0.970, \mathrm{n}=7, \mathrm{p}<\right.$ 0.001]) (Fig. 4B). Similarly, the total cell volume of attached flagellates (Yaf) increased with the increase of $X\left(Y a f=0.0357 X-0.482 \times 10^{5}[\mathrm{r}=0.940, \mathrm{n}=7, \mathrm{p}<\right.$ 0.01]) (Fig. 4C). These results also suggest that large particles are mostly aggregates (rather than flagellate cell bodies), and these aggregates are produced as a linear function of the removal of small particles.

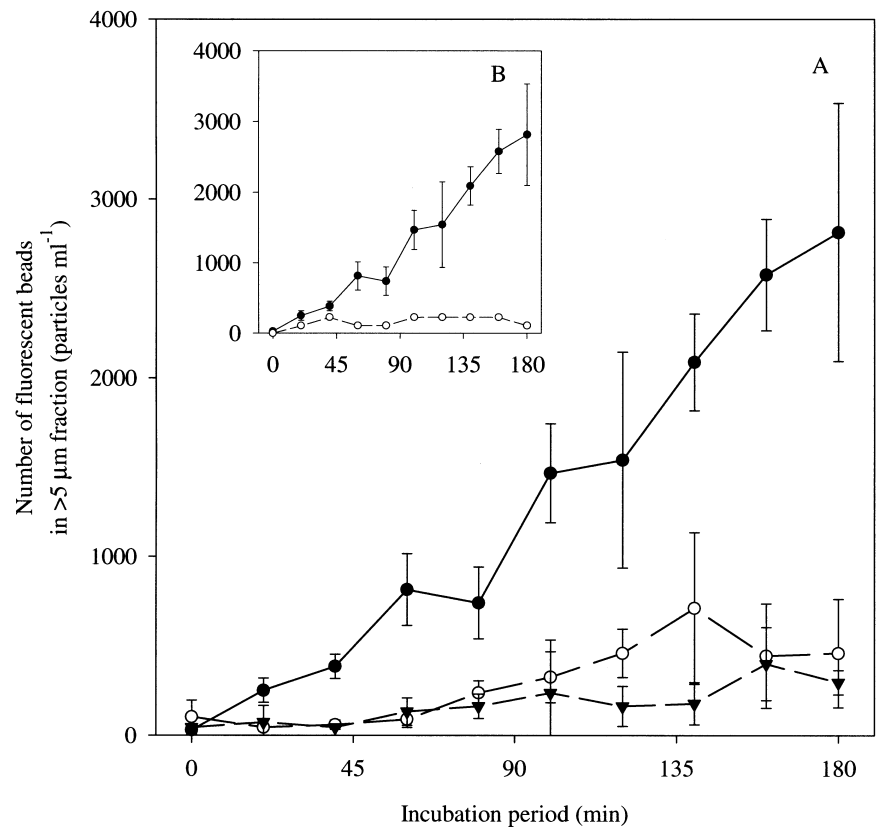

Fig. 5. (A) Time course of the fluorescent bead abundance sorbed in the 5 to $20 \mu \mathrm{m}$ fraction during the culture of Parophysomonas imperforata. Particle number in the 'A-fraction' + 'F-fraction', (free-living and attached flagellates) (•), in the 'F-fraction' + 'heat-killed A-fraction' (only free-living flagellates) (O), and in the 'heat-killed A-fraction' + 'heat-killed F-fraction' (all of the organisms were killed) ( $\mathbf{v})$. (B) Time course of the fluorescent bead abundance sorbed in the 5 to $20 \mu \mathrm{m}$ fraction $(\bullet)$ and in the food vacuole of attached flagellates (O) in the 'A-fraction' + 'F-fraction'. Error bar indicates $\pm 1 \mathrm{SE}$

\section{Experimental transfer of fluorescent beads to large particles in flagellate culture}

Fluorescent beads $(0.5 \mu \mathrm{m})$ were used to determine if attached flagellates enhance adhesion of SMP to larger ones. The rates of the transfer of beads were determined in 3 different mixtures containing different fractions of the flagellate culture. In general, the number of fluorescent beads associated with 5 to $20 \mu \mathrm{m}$ particles linearly increased over the incubation period for up to $180 \mathrm{~min}$ (Fig. 5A). The linear regression analyses showed that the time-dependent increase of the abundance of beads associated with 5 to $20 \mu \mathrm{m}$ particles was significantly higher (ANOVA, p < 0.0001) in the culture with attached flagellates $(930 \pm 72$ particles $\mathrm{ml}^{-1} \mathrm{~h}^{-1}, \mathrm{n}=10$ ) than in the free-living flagellate control $\left(190 \pm 40\right.$ particles $\left.\mathrm{ml}^{-1} \mathrm{~h}^{-1}\right)$ and heat-killed controls $\left(98 \pm 19\right.$ particles $\left.\mathrm{ml}^{-1} \mathrm{~h}^{-1}\right)$. On the other hand, there was no significant difference $(p>0.05)$ in the increase in rates between the free-living and heatkilled controls. These results suggest that the presence of attached flagellates enhanced the transfer of $0.5 \mu \mathrm{m}$ diameter beads from the bulk water phase to large 
(5 to $20 \mu \mathrm{m}$ ) particles, although the relative abundance of both flagellates (attached and free-living) would change during the experiment $(3 \mathrm{~h})$.

Microscopic measurements revealed that the total abundance of beads in food vacuoles of flagellates attached to 5-20 $\mu \mathrm{m}$ particles increased to a maximum of 230 particles $\mathrm{ml}^{-1}$ at $100 \mathrm{~min}$ (Fig. 5B). This maximum value represented $8 \%$ of the total abundance of beads associated with 5 to $20 \mu \mathrm{m}$ particles at the end of the incubation (2800 particles $\mathrm{ml}^{-1}$; Fig. 5B). The ingestion rate of beads by total attached flagellates calculated for the initial 20 min was $170 \pm 98$ particles $\mathrm{ml}^{-1}$ $\mathrm{h}^{-1}\left(\mathrm{n}=3 ; 2.8 \times 10^{-6} \mathrm{nl}\right.$ flagellate $\left.{ }^{-1} \mathrm{~h}^{-1}\right)$. This estimated rate is 5 -fold lower than the transfer rate of beads to the 5 to $20 \mu \mathrm{m}$ particles $\left(930 \pm 72\right.$ particles $\mathrm{ml}^{-1} \mathrm{~h}^{-1}$;
Fig. 5A). The transfer of beads to the 5 to $20 \mu \mathrm{m}$ particles was, therefore, primarily due to adhesion of beads to large particles, and also due to the fact that attached flagellates can significantly enhance the flux of small particles to large particles.

\section{Transfer of fluorescent beads to large particles in coastal seawater}

The bead transfer experiments were also conducted using seawater with various compositions of plankton communities obtained from nutrient-enriched seawater cultures (Table 3). In all the experiments, linear regression analysis showed that the transfer rate of fluores-

Table 3. Summary of biological variables and total surface area of large (5 to $20 \mu \mathrm{m}$ ) particles in seawater culture experiments

\begin{tabular}{|c|c|c|c|c|c|c|c|c|}
\hline $\begin{array}{l}\text { Time after } \\
\text { enrich- } \\
\text { ment (h) }\end{array}$ & Growth phase & $\begin{array}{c}\mathrm{Chl} a \\
\left(\mu \mathrm{g} \mathrm{l}^{-1}\right)\end{array}$ & $\begin{array}{c}\text { Bacteria } \\
\left(10^{6}\right)\end{array}$ & $\begin{array}{r}\text { Cell abun } \\
\text { Flagella } \\
\text { Free-living }\end{array}$ & $\begin{array}{l}\text { dance (cells } \\
\text { es }\left(10^{2}\right) \\
\text { Attached }\end{array}$ & $\begin{array}{l}\text { Ciliates } \mathrm{ml}^{-1} \text { ) } \\
\text { Ciliate }\end{array}$ & $\begin{array}{c}\text { Total } \\
\text { surface area } \\
\left(10^{4} \mu \mathrm{m}^{2} \mathrm{ml}^{-1}\right)\end{array}$ & $\begin{array}{c}\text { Density of } \\
\text { attached flagellates } \\
\left(\text { cells particle }{ }^{-1}\right)\end{array}$ \\
\hline \multicolumn{9}{|c|}{ February 11} \\
\hline 0 & Pre-exponential & 5.84 & 3.1 & 7.7 & 3.0 & $<1$ & 3.6 & 1.2 \\
\hline 72 & Exponential growth & 11.2 & 15 & 75 & 9.1 & 13 & 3.2 & 4.9 \\
\hline 144 & Late-stationary & 7.07 & 1.6 & 87 & 150 & 11 & 22 & 13 \\
\hline 236 & Late-stationary & 13.6 & 1.8 & 56 & 47 & 16 & 8.6 & 8.4 \\
\hline \multicolumn{9}{|l|}{ March 12} \\
\hline 158.5 & Exponential growth & 17.8 & 0.7 & 21 & 7.4 & $<1$ & 97 & 0.12 \\
\hline 207 & Late-stationary & 24.3 & 2.0 & 46 & 19 & $<1$ & 180 & 0.23 \\
\hline \multicolumn{9}{|l|}{ April 5} \\
\hline 142 & Exponential growth & 31.4 & 1.8 & 39 & 17 & $<1$ & 87 & 0.62 \\
\hline 187.5 & Early-stationary & 31.1 & 6.4 & 79 & 34 & $<1$ & 140 & 0.58 \\
\hline 282.5 & Late-stationary & 6.77 & 3.2 & 26 & 38 & $<1$ & 120 & 0.90 \\
\hline 402 & Late-stationary & 3.63 & 7.4 & 12 & 6.1 & 16 & 45 & 0.44 \\
\hline 496 & Late-stationary & 1.72 & 7.0 & 41 & 29 & 32 & 32 & 2.5 \\
\hline
\end{tabular}

Table 4. Transfer rate in 3 different treatment cultures and ingestion rate of protozoa (attached flagellates and ciliates) grazing on fluorescent beads. No: non-treatment culture; Th: Thiuram; Na: $\mathrm{NaN}_{3}$-treated culture

\begin{tabular}{|c|c|c|c|c|c|c|c|}
\hline \multirow{2}{*}{$\begin{array}{l}\text { Time after } \\
\text { enrich- } \\
\text { ment (h) }\end{array}$} & \multicolumn{3}{|c|}{ Transfer rate (particles $\mathrm{ml}^{-1} \mathrm{~h}^{-1} \pm \mathrm{SE}, \mathrm{n}=5$ ) } & \multirow[t]{2}{*}{ No:Na } & \multicolumn{3}{|c|}{ Ingestion rate of beads (particles $\mathrm{ml}^{-1} \mathrm{~h}^{-1}$ ) } \\
\hline & No & Th & $\mathrm{Na}$ & & Flagellates & Ciliates & $\begin{array}{l}\text { Flagellates + Ciliates } \\
\quad(\% \text { to No-Na) }\end{array}$ \\
\hline \multicolumn{8}{|c|}{ February 11} \\
\hline 0 & $92.2 \pm 9.05$ & $44.1 \pm 3.14$ & $17.6 \pm 2.76$ & 5.24 & 4.8 & & $4.8(6.5)$ \\
\hline 72 & $138 \pm 9.71$ & $56.4 \pm 9.22$ & $57.4 \pm 4.06$ & 2.40 & $<7.2$ & 2.3 & $<9.6(12)$ \\
\hline 144 & $186 \pm 24.3$ & $4.75 \pm 1.97$ & $43.4 \pm 5.60$ & 4.29 & $<120$ & 29 & $<150(100)$ \\
\hline 236 & $151 \pm 27.2$ & $31.6 \pm 3.17$ & $54.0 \pm 12.3$ & 2.80 & $<38$ & 6.4 & $<44(46)$ \\
\hline \multicolumn{8}{|l|}{ March 12} \\
\hline 158.5 & $210 \pm 13.3$ & $75.4 \pm 14.9$ & $91.5 \pm 12.6$ & 2.30 & $<9.8$ & & $<9.8(8.3)$ \\
\hline 207 & $340 \pm 14.2$ & $340 \pm 7.67$ & $213 \pm 6.78$ & 1.60 & $<25$ & & $<25(20)$ \\
\hline \multicolumn{8}{|l|}{ April 5} \\
\hline 142 & $169 \pm 8.34$ & $60.2 \pm 17.3$ & $55.3 \pm 8.11$ & 3.06 & 34 & & 34 (30) \\
\hline 187.5 & $206 \pm 24.0$ & $162 \pm 20.6$ & $107 \pm 16.3$ & 1.93 & $<31$ & & $<31$ (15) \\
\hline 282.5 & $465 \pm 51.6$ & $41.5 \pm 1.70$ & $91.9 \pm 26.3$ & 5.06 & $<37$ & & $<37$ (9.8) \\
\hline 402 & $131 \pm 4.83$ & $31.0 \pm 13$ & $24.5 \pm 5.42$ & 5.35 & $<5.3$ & 11 & $<16(15)$ \\
\hline 496 & $340 \pm 15.1$ & $79.7 \pm 8.05$ & $61.2 \pm 10.4$ & 5.56 & $<27$ & 12 & $<40(14)$ \\
\hline
\end{tabular}


cent beads to large (5 to $20 \mu \mathrm{m}$ ) particles in non-treated samples (92.2 to 465 particles $\mathrm{ml}^{-1} \mathrm{~h}^{-1}$ ) during $24 \mathrm{~h}$ incubation was significantly higher $(\mathrm{p}<0.0001)$ than the rate in $\mathrm{NaN}_{3}$-treated controls (17.6 to 107 particles $\mathrm{ml}^{-1}$ $\mathrm{h}^{-1}$; Table 4). Also, the rates of thiuram-treated samples (4.75 to 340 particles $\mathrm{ml}^{-1} \mathrm{~h}^{-1}$ ) were significantly lower $(\mathrm{p}<0.0001)$ than non-treated samples, except after $207 \mathrm{~h}$ in the March experiment. These results strongly suggest the importance of biological processes for the transfer of beads to larger particles.

In these waters, the rates at which attached flagellates and ciliates ingested fluorescent particles were estimated to be 4.8 to $<150$ particles $\mathrm{ml}^{-1} \mathrm{~h}^{-1}$, which accounted for 1 to $30 \%$ of the difference of transfer rate of beads to large particles between non-treatment culture and $\mathrm{NaN}_{3}$-treated culture (No- $\mathrm{Na}$ ), except after 144 and $236 \mathrm{~h}$ in the February experiment (Table 4). Therefore, biological processes other than ingestion of fluorescent beads by protozoa would be important for the transfer of fluorescent beads from the water phase to large particles.

\section{DISCUSSION}

Previous studies have suggested that the grazing of protozoa on bacteria and non-living small particles contributes to the conversion of small particles to large particles in aquatic systems (repackaging effect; Sherr et al. 1988). Less attention, however, has been paid to the possible enhancement of aggregate formation due to protozoan activities other than the ingestion-assimilation processes, e.g. particle transport due to flagella motion of protozoa. To examine the effects of the feeding current of flagellates, we used flow cytometric techniques to measure the transfer rate of model SMP (fluorescent latex beads) into large aggregates. This technique does not need particle collection, such as filtration, and therefore reduces artifacts on particle localization by experimental protocols. In addition, the movement of a single bead is detectable by using fluorescent latex beads as a tracer.

The data presented in this paper provide several lines of evidence that suggest a 'non-ingestive' mechanism by which protozoa can enhance aggregation and enlargement of submicron-sized particles in marine environments. First, large numbers of non-living, large aggregates were produced in a culture of flagellates grazing on heat-killed bacteria (Figs. 3 \& 4). Second, with the presence of attached flagellates, the transfer of model SMP (fluorescent beads) from the bulk water phase to large particles (5 to $20 \mu \mathrm{m}$ ) was substantially enhanced relative to that in heat-killed controls (Fig. 5). The ingestion of fluorescent beads by attached flagellates explained only a small fraction of this en- hancement and this is consistent with microscopic observations of the aggregates (Fig. 1C). This enhancement effect was not detected in the control with only free-living flagellates (Fig. 5). Collectively, the above results are consistent with the hypothesis that the feeding current of flagellates can promote adhesion of SMP to large particles, although alternative explanations may exist. Additionally, in nutrientenriched coastal seawaters, the transfer of model SMP from the water phase to large particles (5 to $20 \mu \mathrm{m}$ ) was significantly reduced with the addition of eucaryotic and respiratory inhibitors, suggesting the role of protozoans in particle dynamics (Table 4). The ingestion of beads by protozoans played a rather minor role in the transfer of beads to large particles. The results of enrichment culture experiments are consistent with our hypothesis, although there were not only attached protozoa but also many other eucaryotes, such as phytoplankton, in the cultures.

To test the potential effect of feeding currents using a particle collision model, we compared the collision rates of SMP with large particles to those in our $\mathrm{NaN}_{3}$ - treated and non-treated culture experiments. Here, we assume that the feeding current of attached flagellates can fully explain the observed difference. The former flow field is caused by primarily differential sedimenting velocity because all eucaryotes were inactivated. On the other hand, the latter flow field is caused not only by differential sedimenting velocity but also by feeding current, which is advective flow (Fig. 2) and is a transport mechanism similar to differential sedimentation. Shimeta (1993) pointed out that diffusional collision caused by an advective flow field around large particles (advective-diffusion) is an important SMP/large particle encounter process. As a first order estimation, we use his advective-diffusion model to examine the effect of feeding current on aggregation processes.

Particle encounter rate, $E$, in an advective-diffusion encounter is calculated as

$$
E=7.98 D^{\frac{2}{3}} U^{\frac{1}{3}} r_{1}^{\frac{4}{3}}
$$

where $D$ is Brownian diffusivity, $U$ is free stream velocity and $r_{1}$ is radius of large particle. $E$ is expressed as fluid volume per unit of time. $D$ is determined by the equation

$$
D=K T / 6 \pi \mu r_{2}
$$

where $K$ is Boltzmann's constant $\left(1.38 \times 10^{-16} \mathrm{~g} \mathrm{~cm}^{2} \mathrm{~s}^{-2}\right.$ $\left.\mathrm{K}^{-1}\right), T$ is temperature in degrees Kelvin, $\mu$ is absolute viscosity and $r_{2}$ is radius of SMP. For differential sedimentation, $U$ is approximated by the sedimenting velocity of large particles, although $U$ should be the difference in sedimenting velocity between SMP and large particle. 


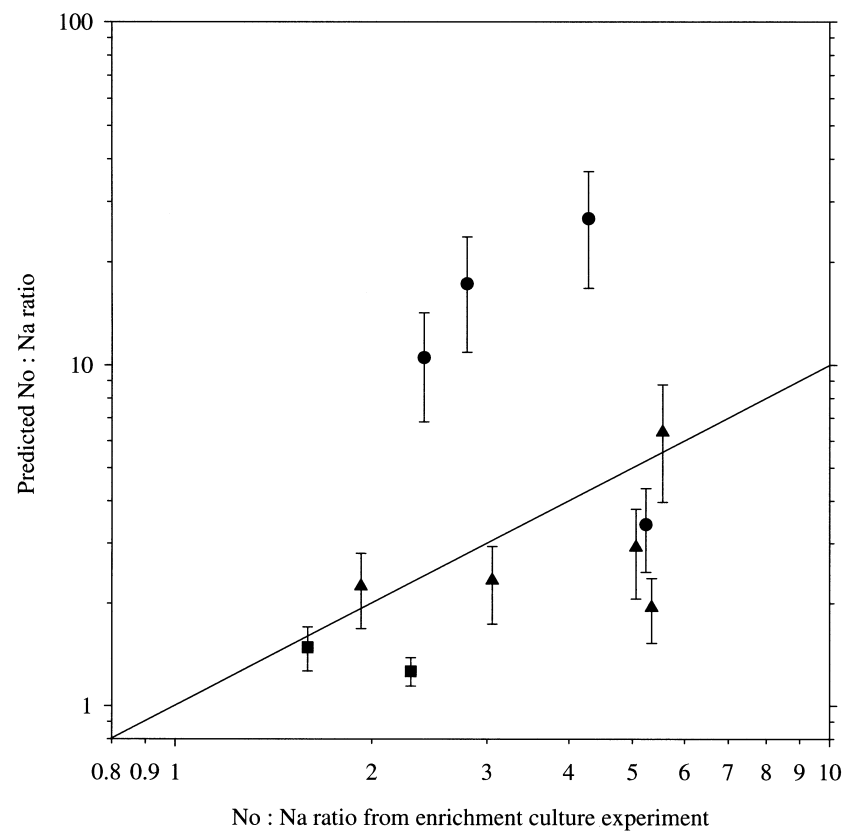

Fig. 6. Comparison of ratio of transfer rate in the non-treated culture to that in the $\mathrm{NaN}_{3}$-treated culture (No:Na) ratio (see Table 4) using data from the 3 enrichment cultures and No:Na ratio predicted from the density of attached flagellates using the advective-diffusion model (Shimeta 1993). At the time of calculation, the velocity of the stream was assumed to be from 5 to $20 \mu \mathrm{m} \mathrm{s}^{-1}$. Bar indicates maximum and minimum of predicted value and symbols indicate median of these values. Experiments using water samples collected on $(\bullet) 11$ February; (ロ) 12 March and on (4) 5 April

In this study, the velocity of fluorescent beads approaching Paraphysomonas imperforata was 5 to $20 \mu \mathrm{m} \mathrm{s}^{-1}$ near the surface of the aggregate, and 25 to $50 \mu \mathrm{m} \mathrm{s}^{-1}$ near the surface of the flagella (from Fig. 2A, D). Assuming this velocity is lower than the swimming speed of free-living nanoflagellates (85 to $360 \mathrm{\mu m} \mathrm{s}^{-1}$; reviewed in Goldman 1984), we can use the velocity near the surface of the aggregate for comparison. The reported sedimenting velocity of 5 to $20 \mu \mathrm{m}$ sized particles in an ocean environment is 1 to $3 \mu \mathrm{m} \mathrm{s}^{-1}$ (Bienfang 1985). The specific gravity of the beads used is 1.05, which may be greater than that of porous marine colloids. However the difference in sedimenting velocity between SMP and 5 to $20 \mu \mathrm{m}$ particles is determined to a greater extent by the size of 5 to $20 \mu \mathrm{m}$ particles than by the difference in density.

The model calculation shows that the feeding current of flagellates could enhance the encounter rate of SMP by 1.2 to 2.7 times because the encounter rate increases in proportion to one-third the power of the advection velocity. In addition, the encounter rate accelerated by a feeding current will increase proportionally when the density of suspension-feeding protozoa attached to aggregate increases. In our study, tracer beads were transferred to small fractions of large particles intensely in non-treatment enrichment cultures. In contrast, beads were transferred to large particles uniformly in $\mathrm{NaN}_{3}$-treated cultures (data not shown).

In order to evaluate the rate of enhancement, the ratio of bead transfer rate in non-treated culture to that in $\mathrm{NaN}_{3}$-treated culture (No:Na) was calculated (Table 4). Fig. 6 shows a comparison of the No:Na ratios based on data determined in enrichment culture experiments and predicted ratios, which are calculated as

$$
\mathrm{No}: \mathrm{Na}=\left(E_{\mathrm{fc}} \times d_{\mathrm{af}}+E_{\mathrm{ds}}\right) / E_{\mathrm{ds}}
$$

where $E_{\mathrm{fc}}$ and $E_{\mathrm{ds}}$ are advective-diffusion rate by feeding current and differential sedimentation, respectively, and $d_{\text {af }}$ is density of attached flagellate. Velocity of feeding current and differential sedimentation are assumed to be from 5 to 20 and 1 to $3 \mu \mathrm{m} \mathrm{s}^{-1}$; respectively (see above).

Although other factors such as turbulent shear may have affected collision probability between particles, except in the February experiment, the model results were consistent with our findings that adhesion of SMP to large particles was significantly enhanced by the presence of attached flagellates in still waters. Predicted ratios from experiments in February, in which attached flagellates heavily colonized phytodetritus, greatly exceeded the ratio determined by the flow cytometer. The existence of protozoa, which graze on adhering bacteria without creating a feeding current, may have caused the observed overestimation of this prediction.

An alternative mechanism by which flagellates may enhance adhesion of SMP to large particles is the excretion of polymers, which may increase the 'stickiness' of particles (Ratsak et al. 1996). It has been observed that flagellates release high amounts of SMP and colloidal particles (Koike et al. 1990, Nagata in press). However, in our experiments with Paraphysomonas imperforata, the adhesion of fluorescent beads to large particles was enhanced only in the presence of attached flagellates. No enhancement was detected in the controls using only free-living flagellates. Because both attached and free-living flagellates could excrete polymers, the feeding current was probably more important than sticky polymers in enhancing the adhesion rate of beads to large particles in our experiments. The possibility of attached flagellates excreting the more sticky matter cannot be discounted. However, the stickiness of heat-killed aggregates is similar to the original aggregates in our bead adhesion experiments (H.F. \& I.K. unpubl. result). Therefore, a drastic change of stickiness during our experiments was not likely, although the production of sticky material by attached flagellates may occur in natural waters. Alldredge \& McGillivarry 
(1991) reported the stickiness of marine snow to be 0.60 for amorphous detrital aggregates and 0.88 for flocculated diatoms. If the stickiness of marine aggregates increases to their maximum value $(=1)$, the coagulation rate will be stimulated only 1.1 - to 1.7 -fold, which is lower than the results of enrichment culture experiments. The effects of excreted polymers on particle aggregation dynamics need further elucidation. In sewage-treatment plants, stimulation of organic aggregate flocculation by protozoa has been reported (reviewed in Ratsak et al. 1996). While excretion of exopolymers from protozoa is one of the possible mechanisms stimulating coagulation, collision by their feeding current would also play a part in the systems.

The 'repackaging effect' caused by ingestion and assimilation of small particles by protozoa is associated with a substantial transformation and loss (respiration) of organic matter due to digestive and metabolic processes. On the other hand, the 'non-ingestive pathway' of particle aggregation that we propose occurs as an auxiliary effect of protozoan feeding behavior and would result in large particle formation without modification of the biochemical characteristics of small particles. This difference may result in a qualitative difference between marine aggregates and sinking particles. And this 'non-ingestive pathway' of collision between non-living particles is different to the other reported biological stimulation of collision such as bacterial motility (Johnson \& Kepkay 1992).

Recent studies have increasingly focused on the role of aggregate-dwelling microbes in particle dynamics in the ocean (Smith et al. 1992), but no previous study has examined the potential enhancement of adhesion of SMP to large particles due to feeding currents of attached flagellates. Although our data are limited to a culture of isolates and enriched coastal waters, the results suggest that this process is potentially important in particle dynamics in coastal and oceanic systems. We calculated the particle removal rate of SMP by absorption to $5-20 \mu \mathrm{m}$ particles in the surface water of Otsuchi Bay $\left(35.0^{\circ} \mathrm{N}, 141.6^{\circ} \mathrm{E}\right.$, Japan) from the data of observation on June 9, 1999 (post phytoplankton bloom: chl a 1.1 to $4.4 \mu \mathrm{g} \mathrm{l}^{-1}$ ) and by using the advective-diffusion model. With an abundance of attached flagellates of 0.7 to $1.5 \times 10^{3}$ cells $\mathrm{ml}^{-1}$ and assuming the velocity of their feeding to be 5 to $20 \mu \mathrm{m} \mathrm{s}^{-1}$ with a collision efficiency (stickiness) of 0.60 to 0.88 (Alldredge \& McGillivary 1991), all SMP could be removed within 8 to $160 \mathrm{~d}$ by the feeding current of flagellates without any particle decomposition.

To examine the effect of the encounter rate by the feeding current of attached flagellates on particle dynamics in a marine environment, however, information about the density of attached flagellates on particles and velocity of the feeding current in the field will be needed. Our future direction is to clarify the distribution of suspension feeding by attached flagellates and determine the factors which affect the feeding current of attached flagellates in relation to food conditions of their natural environment.

Acknowledgements. We thank Toshi Nagata, ORI, University of Tokyo, and Luis M. Tupas, SOEST, University of Hawaii, for helpful comments on the manuscript. This study was supported by a grant from JSPS Research Fellowships for Young Scientists, and by Grant-in-Aid from the Ministry of Education, Science and Culture (07404044), Japan.

\section{LITERATURE CITED}

Alldredge AL, McGillivary P (1991) The attachment probabilities of marine snow and their implications for particle coagulation in the ocean. Deep-Sea Res 38:431-443

Alldredge AL, Passow U, Logan BE (1993) The abundance and significance of class of large transparent organic particles in the ocean. Deep-Sea Res 40:1-17

Banse K (1990) New views on the degradation and disposition of organic particles as collected by sediment traps in the open sea. Deep-Sea Res 37:1177-1195

Bienfang PK (1985) Size structure and sinking rates of various microparticulate constituents in oligotrophic Hawaiian waters. Mar Ecol Prog Ser 23:143-151

Buffle J, Wilkinson KJ, Stoll S, Filella M, Zhang J (1998) A generalized description of aquatic colloidal inateractions: the three-colloidal component approach. Environ Sci Technol 32:2887-2889

Caron DA, Davis PG, Madin LP, Sieburth JMN (1982) Heterotrophic bacteria and bacterivorous protozoa in oceanic macroaggregates. Science 218:795-797

Dagg M (1993) Sinking particles as a possible source of nutrition for the large calanoid Neocalanus cristatus in the subarctic Pacific. Deep-Sea Res 40:1431-1445

Goldman JC (1984) Conceptual role for microaggregation in pelagic waters. Bull Mar Sci 35:462-476

Jackson GA, Burd AB (1998) Aggregation in the marine environment. Environ Sci Technol 32:2805-2814

Johnson BD, Kepkay PE (1992) Colloid transport and bacterial utilization of oceanic DOC. Deep-Sea Res 39:855-869

Kepkay PE (1994) Particle aggregation and the biological activity of colloids. Mar Ecol Prog Ser 109:293-304

Koike I, Hara S, Terauchi K, Kogure K (1990) Role of submicrometre particles in the ocean. Nature 345:242-244

Lundsgaard C, Olesen M (1997) The origin of sedimenting detrital matter in a coastal system. Limnol Oceanogr 42: 1001-1005

Mari X, Burd A (1998) Seasonal size spectra of transparent exopolymeric particles (TEP) in a coastal sea and comparison with those predicted using coagulation theory. Mar Ecol Prog Ser 163:63-76

Nagata T (in press) 'Picopellets' produced by phagotrophic nanoflagellates: role in the material cycling within marine environments. In: Handa N, Tanoue E, Hama T (eds) Biogeochemistry of marine organic matter. Terra Scientific Publishing Company, Tokyo

Nagata T, Kirchman DL (1991) Release of dissolved free and combined amino acids by bacterivorous marine flagellates. Limnol Oceanogr 36:433-443

Nagata T, Kirchman DL (1997) Roles of submicron particle and colloids in microbial food webs and biogeochemical 
cycles within marine environments. Adv Microb Ecol 15: 81-103

Nagata T, Koike I (1996) Marine colloids: their roles in food webs and geochemical fluxes. In: Sakai H, Nozaki Y (eds) Biogeochemical processes and ocean flux in the western Pacific. Terra Scientific Publishing Company, Tokyo, p 275-292

Porter KG, Feig YS (1980) The use of DAPI for identifying and counting aquatic microflora. Limnol Oceanogr 25:943-948

Ratsak CH, Maarsen KA, Kooijman SALM (1996) Effects of protozoa on carbon mineralization in activated sludge. Wat Res 30:1-12

Sherr BF, Sherr EB (1983) Enumeration of heterotrophic microprotozoa by epifluorescence microscopy. Estuar Coast Shelf Sci 16:1-7

Sherr BF, Sherr EB, Fallon RD (1987) Use of monodispersed, fluorescently labelled bacteria to estimate in situ protozoan bacterivory. Appl Environ Microbiol 53:958-965

Sherr BF, Sherr EB, Berman T (1988) Role of microbes in pelagic food webs: a revised concept. Limnol Oceanogr 33:1225-1227

Shimeta J (1993) Diffusional encounter of submicrometer particles and small cells by suspension feeders. Limnol Oceanogr 38:456-465

Shimeta J, Jumars PA (1991) Physical mechanisms and rates

Editorial responsibility: John Austin (Assistant Editor), Oldendorf/Luhe, Germany of particle capture by suspention feeders. Oceanogr Mar Biol Annu Rev 29:191-257

Sieracki ME, Hass LW, Caron DA, Lessard EJ (1987) The effect of fixation on particle retention by microflagellates: underestimation of grazing rates. Mar Ecol Prog Ser 38: 251-258

Silver MW, Gowing MM, Brownlee DC, Corliss JO (1984) Ciliated protozoa associated with oceanic sinking detritus. Nature 309:246-248

Smith DC, Simon M, Alldredge AL, Azam F (1992) Intense hydrolytic enzyme activity on marine aggregates and implications for rapid particle dissolution. Nature 359: $139-142$

Suzuki R, Ishimaru T (1990) An improve method for the determination of phytoplankton chlorophyll using $N, N$ di-metylfolmamide. J Oceanogr Soc Jpn 46:190-194

Taylor GT, Pace ML (1987) Validity of eucaryote inhibitors for assessing production and grazing mortality of marine bacterioplankton. Appl Environ Microbiol 53:119-128

Yamasaki A, Fukuda H, Fukuda R, Miyajima T, Nagata T, Ogawa H, Koike I (1998) Submicrometer particles in northwest Pacific coastal environments: abundance, size distribution, and biological origins. Limnol Oceanogr 43: 536-542

Submitted: October 8, 1999; Accepted: February 8, 2000 Proofs received from author(s): August 7, 2000 